\title{
PERSPECTIVES ON HAPPINESS ACCORDING TO ORTEGA Y GASSET
}

In Happiness And Contemporary Society : Conference Proceedings Volume (Lviv, March, 20-21, 2021). Lviv: SPOLOM, 2021. P. 270-274. https://doi.org/10.31108/7.2021.60

ISBN 978-966-919-697-2 


\author{
VISCOMI Marco \\ Ph.D. in Theoretical Philosophy \\ Università degli Studi di Perugia (Perugia, Italy)
}

\title{
PERSPECTIVES ON HAPPINESS ACCORDING TO ORTEGA Y GASSET
}

The content of this short essay aims to collect some insights provided by José Ortega y Gasset on happiness. The Spanish thinker does not dedicate a systematic work to the deepening of this important issue, but nevertheless he provides some interesting considerations for a more detailed and meticulous study on this subject. In fact, there are not many points in Ortega's work in which he directly provides his own considerations on happiness, but the observations granted by the philosopher are interesting for our contemporary meditation. The thoughts here reconstructed in expressive unity converge starting from some specific points of Ortega's opera omnia. This work of reconstruction and essential synthesis is intended to offer a philosophical contribution to the most comprehensive and organic reflection on happiness. The implicit hope contained in this text would like to leave available this questioning both for its existentialist dimensions and for its anthropological and sociological openings, which constitutively belong to the discussion of happiness.

Keywords: Ortega y Gasset, happiness, human essence, personalism, vitalism

Following an initial indication of Ortega, happiness could be defined as the will of the human being to find something that satisfies him completely ${ }^{4}$. It is not simply a matter of determining the satisfaction of a need or necessity, but rather of putting the focus on the adverb "completely". Happiness, in fact, does not consist of a single element that provides satisfaction or fulfilment, but in an overall state of being, in which our individual existence rests in its entirety ${ }^{5}$. If we accept this primary definition of happiness, however, we have to face two new sets of questions. On the one hand, it arises the problem of determining, from the side of the individual's personal subjectivity, what the full satisfaction that has just been mentioned consists. On the other hand, we must ask ourselves what the objective conditions of a thing or an element are, so that it can actually succeed in satisfying us. In order to untangle the dialectic between subjective and objective that is thus taking shape, Ortega identifies a key term in the action. In fact, the philosopher underlines that, when it places himself in front of the things of the world with which it enters into a relationship, the subject is constitutively

\footnotetext{
${ }^{4}$ For an essential bibliography on the author and his thought, see: J. Ferrater Mora, Ortega y Gasset: etapas de una filosofia, Seix Barral, Barcelona 1958; C. Morón Arroyo, El sistema de Ortega y Gasset, Ediciones Alcalá, Madrid 1968; W. Silver, Ortega as phenomenologist. The genesis of «Meditations on Quixote», Columbia University Press, New York 1978; N. R. Orringer, Ortega y sus fuentes germanicas, Editorial Gredos, Madrid 1979; A. Savignano, J. Ortega y Gasset: la ragion vitale e storica, Sansoni, Florence 1984; A. Savignano, Unamuno, Ortega, Zubiri: tre voci della filosofia del Novecento, Guida, Naples 1989.

${ }^{5}$ Cfr. J. Ortega y Gasset, Teoría de la felicidad, in Obras completas, Tomo 2, Alianza Editorial, Madrid 1983, pp. 79-80.
} 
pure activity. Our existence, by the very fact of not being an abstraction but an embodied, living and vital reality, consists of a bundle of activities. We are a skein that wraps itself between factual practices and aspirations to action: it is precisely in these tensions between being and wanting to be, between existing and fulfilling oneself in always different and distinct ways, that lies the beating heart of our aspiration to happiness.

Man is the explosive compound of a potentiality of acts, which from time to time are realized in the practice of action or that aspire to this concretization, kicking inside the human mind in the forms of desire and aspiration. Motivation, stimulus, disposition and implementation of our eagerness, however, do not embody what happiness can be reduced to. As Ortega suggests, desires do not shape the whole personality of an individual, who is much more than just his inner conflicts and the relationship of such spiritual ego struggles with the world outside him ${ }^{6}$. The path marked by the will of the individuality itself indicates only in backlight how happiness is to be thought. Following the suggestions of the Spanish thinker, in fact, the most important indication for determining the status of happiness is to observe what its opposite consists of. According to Ortega, unhappiness depends on the fact that things, towards which our desire and our action lean, leave within us wider or narrower portions of emptiness. That part of vacant, inactive vitality, not exercised in action to any order of acting; such a specific state of meaningless, inert and apathetic emptiness is unhappiness. Ortega asserts that the condition of those who are not totally absorbed in the occupation drags them more and more towards a state of unhappiness, since being happy should mean - in thinker's understanding - the opposite of unemployment, of inactivity. Standing still, in fact, not affecting the subjective vitality of confronting with world's objectivity, of clashing with it to achieve the success of one's action, leads to the defeat of one's life ${ }^{7}$. It is exactly the existence that, in this state, folds upon itself and locks itself up in melancholy and discontent. The sadness that so arises within the ego mingles with that state of deep depression that can be seen in the expressions "I am unhappy", "I feel unhappy".

There is an interesting relationship between action as such and inactivity as a closure of the ego in itself. According to Ortega's direct expression, «en cierto modo, vivir y sentirse vivir son dos cosas incompatibles $\rangle^{8}$. Consider, as below, the implicit meaning in this sentence. When the ego is totally poured into action, the inner dimension of self-reflection is overwhelmed by the clamor in which the two worlds of the subjective and the objective collide. These two levels are, respectively, the level of individual aspirations and that of the circumstances in which a particular person is placed. If, on the other hand, the action exercised by the ego comes closer and closer to the degree of inactivity, then that precise individual consciousness will increasingly feel

\footnotetext{
${ }^{6}$ Cfr. ivi, p. 81 , note 1.

7 Ortega points out that existence is pain and suffering precisely because we cannot exempt ourselves from action, always having to confront with it in order to exist and to become what we authentically are. Conquered in the shipwreck of existence, we do not drown, unless we allow ourselves to die in the suicide of pragmatist dispersion or spiritual implosion. Cfr. J. Ortega y Gasset, Prólogo para alemanes, in Obras completas, Tomo 8, Alianza Editorial, Madrid 1983, pp. 44-53.

8 J. Ortega y Gasset, Teoría de la felicidad, in Obras completas, Tomo 2, Alianza Editorial, Madrid 1983, p. 82: «in a certain sense, living and feeling alive are two incompatible things».
} 
the echo of its own thoughts, the hidden aspirations of its own desire, the ghosts of its subconscious. The action performed by the ego assumes in itself an existentially pregnant value, when that action achieves happiness as a concrete action. The absolute inactivity of the ego, on the other hand, plunges the subject into the abyss of its subconscious: if it remains for too long in this depth without returning to the factual world of action, the ego condemns itself to the unhappy metamorphosis of its own personality into pure yearning, lump of unfulfilled intentions, paralized tendencies, repressed attempts?.

Now, when it comes to the question of happiness, although it is fundamental to recognize the essential feature that belongs to the subject-object conflict, it is nevertheless an error to absolutize the action to the detriment of meditation or introversion. The interiority does not coincide tout court with the immobility which determines not only neurosis and sloth, but also - in a certain way - unhappiness. Entering within himself, man does not stop living or being, simply because he does not act in a practical or factual way. In the ego there is the source of unhappiness, only in the sense that this ontological condition onsets when man takes refuge in himself as inside the cloister in which he freely chooses to become unhappy. Ultimately, inactivity moves one away from happiness only when the rejection of the action coincides with the denial of the objective world and of the factual circumstances, with which the single subject has to fight to realize himself and his aspirations. Just as happiness does not consist of a mere neurotic and hysterical activism, incapable of meditation, conscience and peace; equally unhappiness does not result only from the return of the ego into itself, nor from the excavation work that the conscious part of the subject performs in reconstructing the unity of his own psyche. According to Ortega, happiness is found in the relationship between subjective and objective, interior and exterior, aspirations and circumstances; happiness is exactly in the middle point of balance between these pairs of poles, since unhappiness occurs both as a melancholy closure of the ego in itself, and as a neurotic scattering of the ego in the world.

Thinking that happiness consists only in action, regardless of the interiority of the self and to the right balance between subjective and objective: this is the error that Ortega attributes to that mechanistic conception of the psyche, which has become dominant in contemporary society. In a reality in which the deepest instances of the ego are canceled out in unbridled activism and in the absence of self-reflection, the thinker sentences: «tiene [el hombre medio] el alma hueca, y su única actividad es el eco» ${ }^{10}$. The ego possesses in itself the need that pushes it not only towards the world, to satisfy its desires in objective reality, but also towards itself, towards the deep self. Those who limit themselves to the conventional meaning of "I" and neglect any kind of spiritual depth, totally pouring themselves into unscrupulous activism, condemn themselves to the superficiality of what is external. Such a subject, like someone who pathologically closes himself in the cell of his own melancholy, meets unhappiness. In both cases, what distances man from happiness is his disposition to choose and live his own existence as a "farce" 11 . If one does not embrace real life and the struggle for and of the existence in

\footnotetext{
${ }^{9}$ Cfr. ivi, p. 82.

${ }^{10} \mathrm{Ivi}$, p. 83: «the soul [of the average man] is empty and his only activity is the echo».

11 This is the key word adopted by Ortega to indicate the need that man has to remain on the conflictual dimension between subjective and objective, interior and exterior. This is so that existence remains dynamic and, indeed, vital for the single person who acts in the world and
} 
every dimension of what is vital, the existence capable of this negative choice moves away from itself and from its own realization. To deny to oneself, to one's ego, the realization of what each one is in his own inner self, means as much to deprive oneself of contact with the world, as to prevent oneself from achieving the authenticity of one's deepest self. In Ortega's words, this is the "truth of man", which «estriba en la correspondencia exacta entre gesto y el espiritu, en la perfecta adecuación entre lo externo y lo intimo» ${ }^{12}$.

Explaining the definition of action more accurately, Ortega clarifies even more the way in which his perspective of reflection should be understood. Wanting to assign a broad determination to that concept, the thinker argues that action is «la vida entera de nuestra conciencia cuando está ocupada en la trasformación de la realidad $\rangle^{13}$. This work of transformation is twofold, as it cannot be reduced either to the mere manipulation of what is tangible, nor to the reserving of the ego within its own cocoon. In the balance between the interiority, capable of intimacy with itself, and the extroflexion of practical action, lies that capacity of metamorphosis, in which the ego operates simultaneously on the world and on itself. The road to happiness is embodied in this simultaneous and dialectical action. In fact, just as happiness does not relate to the possession of something or to the achievement of a single aim, equally there remains an indeterminate and constant tension like the rhythm of existence itself, the very breath of human life. In the same way as can be observed for the metaphor of breathing, in which there can be neither only inhalation, nor exclusively exhalation, the ego cannot be happy neither by closing itself in the intellectualism of introversion, nor by destroying itself in the neurotic practice of "action by action" 14 . Human existence is not a problem of practical functioning, nor it can be solved in the abstraction of a conceptual procedure that dissociates the personal and individual self from itself.

Ortega observes in general that the existence that each one of us lives is given to us empty. In it there is not only that long series of needs, which we must satisfy in order to survive ${ }^{15}$. Human life is not simply subsisting, passing through physiological needs as any animal could do. The obligatory occupations of life do not coincide with existence, nor do they identify the more proper dimension of existing, which rather points in the direction of happiness. By disposing ourself to question what makes us persons, regardless of the physical individuality to which we are in any case and always subject, we pursue the authenticity of our life. Stretched out between the extremes already considered above, existence glimpses happiness between actions carried out for the necessity of survival and deliberately acting, chosen to occupy the empty space that life intrinsically is ${ }^{16}$. In carrying out those actions to which we feel called from within, we

among men in relation to their aspirations and to the purposes of the actions they decide to perform. Cfr. ivi, pp. 84-88.

12 Ivi, p. 85: «arises from the exact correspondence between action and spirit, in the perfect reciprocal adaptation between what is external and what is internal»».

${ }^{13}$ Ivi, p. 90: «the whole life of our consciousness when it is engaged in the transformation of reality».

${ }^{14}$ Cfr. ivi, pp. 91-93.

${ }^{15}$ Cfr. J. Ortega y Gasset, $A$ «Veinte años de la caza mayor» del conte de Yebes, in Obras completas, Tomo 6, Alianza Editorial, Madrid 1983, pp. 421.

${ }^{16}$ Cfr. ivi, p. 422. 
fulfill our single vocation and, by acting in this way, we embody what every single human being is called to, namely his personal happiness ${ }^{17}$. Ortega writes: «en verdad, que absortos en una ocupación feliz sentimos un regusto, como estelar, de eternidad $\rangle^{18}$. The authentication of our existence consists in acting in a manner pertinent to our original aspiration to personal happiness. In this way, the specific vocation of man is revealed in the more specific occupations that bring happiness to the individual ${ }^{19}$.

It is clear that in every happiness there is pleasure, but this does not coincide with that. Pleasure is primarily linked to the satisfaction of needs, first of all by approaching the needs of existence and only by extension to the authentic reality of happiness ${ }^{20}$. The actions that are on the way to happiness are not reducible to transitory pleasures of life, as they rather represent constant efforts in which the employed energy reaches out towards a aim, desired but never achievable in a total possession. Happiness precisely consists in this vitality of wanting-to-be and having-to-act, so that the ego would be fulfilled in that unique and unrepeatable tension which is one's own individual existence. Life, Ortega summarises, is not something that is simply present as an object, but as a continuous doing, an action in progress that remains in the stream of its own flow as a continuous changing ${ }^{21}$. By participating in this persistent transformation and taking actively part in it, the human being realizes itself, fulfills his happiness and thus becomes happy, that is - which is the same - it properly becomes itself. As paradoxical living being, which has in itself the character of being an indefinite finitude, an unlimitable or elastic limitation ${ }^{22}$, man is capable of aspiring and reaching out to happiness. It must be understood as a state of living's consciousness which ultimately represents an everchanging and mutable space-time. Here man feels at home in the world, even though it can never really be definitively "happy" anywhere and in any time of this world.

\section{REFERENCES}

1. Ferrater Mora J., Ortega y Gasset: etapas de una filosofia, Seix Barral, Barcelona 1958 ;

2. Morón Arroyo C., El sistema de Ortega y Gasset, Ediciones Alcalá, Madrid 1968;

3. Orringer N.R., Ortega y sus fuentes germanicas, Editorial Gredos, Madrid 1979;

4. Ortega y Gasset J., Obras completas, Tomos 2, 6, 7, 8, Alianza Editorial, Madrid 1983;

5. Savignano A., J. Ortega y Gasset: la ragion vitale e storica, Sansoni, Florence 1984;

6. Savignano A., Unamuno, Ortega, Zubiri: tre voci della filosofia del Novecento, Guida, Naples 1989;

7. Silver W., Ortega as phenomenologist. The genesis of «Meditations on Quixote», Columbia University Press, New York 1978.

\footnotetext{
${ }^{17}$ Cfr. ivi, p. 423.

${ }^{18} I v i$, p. 424: «in truth, when we immerse ourselves in an occupation that makes us happy, a certain taste, almost stellar, of eternity remains in our mouth».

${ }^{19}$ Cfr. ivi, p. 424.

${ }^{20}$ Cfr. ivi, p. 428.

${ }^{21}$ Cfr. J. Ortega y Gasset, El hombre y la gente, in Obras completas, Tomo 7, Alianza Editorial, Madrid 1983, pp. 106-112.

${ }^{22}$ J. Ortega y Gasset, ¿Qué es filosofia?, in Obras completas, Tomo 7, Alianza Editorial, Madrid 1983, pp. 407-420.
} 